\title{
Contribution of Islamic Education Values in Marriage Tradition of Banggai Ethnic, Indonesia
}

\author{
Oyan D. Taufik ${ }^{*}$, Sagaf S. Pettalongi ${ }^{2}$, Sidik Sidik ${ }^{3}$ \\ ${ }^{1}$ Islamic Education Department, Postgraduate, Institut Agama Islam Negeri Palu \\ 2 Islamic Education Department, Postgraduate, Institut Agama Islam Negeri Palu \\ ${ }^{3}$ Islamic Education Department, Postgraduate, Institut Agama Islam Negeri Palu
}

\begin{abstract}
The aim of this article is to find out the contribution of Islamic education values in marriage according to the customs of the tribe in district of Banggai Bulagi. This study used qualitative method. While the data was gathered through direct observation, interviews, and document. The results show that (1) the tradition of pasai is carried out with the intention of fulfilling the provisions of the applicable customs and helping to meet the costs of holding the wedding party in the women's family. (2) implementation of marriage according to the customs of the Bulagi tribe only through poiyas stage. Then the realization of the values of the Islamic education in marriage according to the customs of the tribe of Banggai district of Bulagi consists of three extant value i.e. value of belief, value of equality, and the value of morals. (3) A marriage according to the Banggai customs, carried out in accordance with customary paths and stages, is more steady in understanding the values of Islamic education. The implication of this research is, the role of religious figures, custom figures, public figures, are very influential on society of the tribe in the village of Banggai Bulagi to keep the value of education of Islam applied in any tradition and instilling the teachings of Islamic religion to the younger generation to avoid pregnancy outside of marriage.
\end{abstract}

ARTICLE

INFORMATION 


\section{Introduction}

The values of Islamic education in Banggai customary marriage make a significant positive contribution to the married couples, supporting the implementation process through the stages that have been mutually agreed upon for the Banggai custom. Symbols in these stages must be completed by the married couple so that they will bring forth children who have aqidah, syariah, and noble character.

The value of Islamic education is a collection of interrelated principles that contain the teachings of religion to maintain and develop the human nature towards the formation of a whole human being (insan kamil) in accordance with Islamic norms or teachings.

The manifestation of Islamic education value in the marriage tradition is; 1) Divine value which is the value of faith in Allah SWT and the Prophet (PBUH). 2) Moral education value, including human attitudes to Allah, to the prophet, to oneself, to family, neighbors, fellow Muslims and to non-Muslims. In Islam, morals is also known as ethics. Ethics is a science that concerns with the meaning of good and bad, explains what humans should do to others, states the goals that humans must aim in their actions and shows the way to act. So, ethics is a good deed performed by human being based on their own awareness.

Selecting a marriage partner must undergo the Po Iyas process, meaning that the marriage is carried out on the basis of mutual liking by both family. As for the marriage through this process, the stages are carried out from beginning to end. As for Pasai in the customary marriages is two Baki, one sago grove and a pair of rooster and hen which implies that their wealth and offspring will increase in numbers symbolized by the sago with many shoots and chickens with many chicks.

According to Banggai customary beliefs, practicing the meaning of symbols of each stages in the process of married life is the inculcation of the basic values of Islamic education for the growth and development of their offspring based on faith, Islam, and endeavor in their life both in this world and in the afterlife.

As explained above that values shows the most important thing in human life or something that is most valuable to humans. Therefore, when viewed from Islamic education perspective, values are a way of life that proceeds in the ritual area and the need to live the values of divinity. This is where humans need guidance and procedures for good worship, pray right, behave properly, etc. ${ }^{1}$

Talking about culture for the Banggai tribe, it is quite difficult to describe in words at that time because when holding traditional rituals, for example, all residents poured over to the location where the ritual was carried out. All materials needed for the ritual are contributions from the surrounding people. In customary cases, the papa tua / tete as the head of custom himself becomes the moderator as well as

1Deden Makbhuloh, Pendidikan Agama Islam Arah Baru Pengembangan Ilmu dan Kepribadian di Perguruan Tinggi, (Jakarta: PT. Grafindo Persada, 2011), 155

e-ISSN: 2715-4572

p-ISSN: 2716-1439 
imposes customary sanctions in the case closing process. The principle of transparency and the absence of restrictions in issuing opinions become some added values in the implementation of this customary case sequence. Decisions taken prioritize the aspects of justice will be accepted by all litigants.

Adi Soko was the first who instilled the values of Islamic teachings in Banggai Islands. Nowadays, some customs have changed a lot in terms of marriage culture that contains Islamic teachings. The traditional wedding ceremonies have started to disappear. Marriage as an important event for humans, are necessary to be kept sacred and remembered through a traditional ceremony. However, instead of maintaining it as their identity, some indigenous tribes chose to marry in the modern way even though the values of wisdom are very much contained in traditional marriages.

Responding to the problems currently being faced by the Banggai Tribe, it is interesting to be investigated as a construction that is used as a reference in forming generations who understand and implement the values of Islamic education in marriage according to the customs of the Banggai Islands, as well as understanding and carry out Islamic teachings properly and correctly by taking resources from the Koran and the Hadith of the Prophet.

\section{Literature Review}

\subsection{The purpose of marriage in Islam}

Marriage is a human nature, thus the legal way to meet this need is through aqad nikah (marriage), not in a nasty manner such as dating, kumpul kebo (live together without being married), prostitution, adultery, LGBT, etc. which is distorted and forbidden by Islam.

Marriage in Islam, among others, is to fortify human dignity from bad and abominable deeds, which have degraded and put down noble human dignity. Islam views marriage and family formation as an effective means of caring for young men and women from damage, and protecting society from chaos.

More importantly, marriage is not merely to have children, but to build and form a quality generation who are righteous and devoted to God.

Of course righteous descent will not be obtained but with a true Islamic education. We say this because there are many "Islamic Educational Institutions", but the contents and methods are not Islamic. So many of us see the children of Muslims do not have Islamic morality, due to wrong education. Therefore husband and wife are responsible for educating, teaching, and directing their children to the right path.

Regarding the purpose of marriage, Islam also views the formation of the family as one way to realize greater goals which include various social aspects based on Islam that will have a large and fundamental influence on Muslims and the existence of Muslims. Islam has provided a clear concept and procedure or process of marriage based on the Al-Quran and authentic Sunnah. 


\subsection{Marriage in the Customs' Perspective}

It is human nature that two people of different sexes, man and woman, have the same desire to know each other, observe, and get married. A marriage then brings forth the rights and obligations between the husband and wife reciprocally. Likewise when a child is born, there will also be reciprocal rights and obligations between parents and children.

Sexual need is a difficult-tocontain and always-causes-concerns urge. Therefore, Islam requires the establishment of relation between men and women to be bound in a marriage institution. ${ }^{2}$

In principle, marriage is a contract to justify relations and limit rights and obligations, support and help between man and woman who are not mahram. From a legal standpoint, marriage is a sacred and noble contract between a man and woman that legitimate their status as husband and wife and allow sexual relations aimed at building a sakinah, loving and benevolent family and caring for each other. ${ }^{3}$

The concept of marriage had existed before Islam came. When Islam emerged, cultural accommodation took place between local concepts and Islam. The result of such accommodation is a marriage system that follows the Islamic way, but some systems ordinances that

\footnotetext{
2Quraish Shihab, Wawasan Al-Qur'an Tafsir Maudhu'I atas Berbagai Persoalan Umat,Selanjutnya disebut Wawasan) (Jakarta: Mizan, 1990), 254

3Sudarsono, Hukum Perkawinan Nasional, (Jakarta: PT.Rineka Cipta, 1991), 1
}

accompany the ritual still show the local side, such as procedures for applying, forms of dowry, marriage party, etc., so that the whole process of accommodation transformed into cultural assimilation, in which each value is integrated with one another.

Humans are not only "religious" creatures but also cultural beings. Cultural beings are creatures of wisdom that are able to develop the principles, values and norms in their lives. With reasoning, human can give their endeavors and be able to make beauty in the creation of the universe. ${ }^{4}$

Ernits Casser stated that the cultured community has characteristics in their religious rituals activities, including in their ritual ceremonies. The traditional ceremony as a social institution is filled with symbols that acts as a mean of communication between individuals and groups and serves as a link between the real world and the mystical world. For individuals who participate in it, the elements derived from the mystical world will appear to be real. In their understanding of symbols, humans think. Feeling and thinking with symbolic considerations represent the characteristics of humans so they are called animal syimbolycum. ${ }^{5}$

Each tribe has a traditional tradition even though sometimes it is done without understanding the meaning of what their ancestors did. However, not all traditional values

${ }^{4}$ Rohiman Notowigdagno, Ilmu Budaya Dasar Berdasarkan Al-Qur'an dan Hadits ( Jakarta: Taragrafindo Persada, 2000), 22

${ }^{5}$ Ernits Casser, Manusia dan Kebudayaa (Jakarta: PT Gramedia, 1987), 7

e-ISSN: 2715-4572

p-ISSN: 2716-1439 
passed down through the community are in line with religious life. These cultural values and customs in practice, if viewed from Islamic perspective, some will be found to be contrary to the principles of truth. On the other hand, there are also rituals of worship and their social practices are justified by Islamic law. ${ }^{6}$

In Islam, custom or tradition is seen as a source of law. This shows that Islamic law (shari'ah) provides space for custom or culture that can be adapted in the whole concept of shari'ah. Customs or traditions that can be adapted in the shari'ah system are referred to as 'urf. the formation of 'urf stems from the mutual understanding of many people despite of their different social stratifications. ${ }^{7}$

Custom means a procedure, deed or habit commonly practiced by a person or group of people relating to religion, beliefs and others which is still valid from the beginning to the present days and is still accepted by most of the local community. ${ }^{8}$ Custom is a code of conduct which remains eternal and has strong integration with patterns of community behavior. Community members who violate them will receive harsh sanctions for their own actions. ${ }^{9}$

6Rohimin, Harmonisasi Agama dan Budaya di Indonesia (Jakarta: PT. Nusantara lestari Ceriapratama, 2009), 5

${ }^{7}$ Abdul Wahab Khallaf, Ilmu Ushul Fighi (Indonesia: al-Haramain, 2004), 89

${ }^{8}$ Rusli, R. (2013). The Role of Musalahah in Conflict Resolution: A Historical Perspective. Hunafa: Jurnal Studia Islamika, 10(2), 203-220.

9Rafael Raga Maran, Manusia Dan Kebudayaan dalam Perspektif Ilmu Budaya Dasar. (Jakarta : Rineka Cipta, 2007), 41
According to Kusumadi Pudjosewojo that "Custom is the behavior done by and exist in a community (was, is, will be) carried out. And there are thick customs, some are thin, and always thicken and thin out. The rules of human behavior in the community as intended earlier are customary rules. ${ }^{10}$

\subsection{Islamic Education Values}

Fundamental Islamic values that contain absoluteness for human life as a person and as members of society do not tend to change to follow human passions that change according to the demands of social change. Islamic values that are absolute from God, will function as controllers or directors of the demands of social change and individual demands.

The configuration of Islamic values may change, but intristically these values remain unchanged because if the intristic values change then the meaning of revelation from the source of values in the form of the Holy Qur'an, will be damaged.

Thus Islamic values in theological aspects have never changed, but from the aspect of practice they may claim changes according to the demands of the times and the environment. On the contrary, human values are always experiencing developments and changes towards more advanced and higher directions. The role of education is to combine new values with the old ones in a selective, innovative and

10Iman Sudiyat, Asas-Asas Hukum Adat Bekal Pengantar, (Yogyakarta : Liberty, 1978), 14 e-ISSN: 2715-4572 p-ISSN: 2716-1439 
accommodative manner for the development of education in accordance with the demands of the times and circumstances, without abandoning fundamental values that serve as benchmarks for new values. ${ }^{11}$

If at any time a conflict occurs between Islamic and non-Islamic values, the function and role of education is to actualize and function these Islamic values when there is a change in modern society with the power of science and technology. Education must resolve the conflict between internal-intrinsic values, good-bad, according to Islamic norms with positive or negative external-extrinsic values harmoniously in the Islamic society without causing mental-spiritual tensions that develop into negative and distructive behavior in moral and social life.

Islamic education is in charge of instilling and developing the continuity of the functioning of Islamic values originated from al-Quran and al-Hadith, keeping in line with the demands of society due to cultural influences, and providing flexibility in the development of values within the scope of configuration.

Islamic education is actually obliged to expand the range of configurations of Islamic values, so that every Muslim will be able to conduct a

11 Evita, E., Syahid, A., \& Nurdin, N. (2019). Understanding Students' Learning Outcomes Differences Through the Application of the Market Place Activity Type of Cooperative Learning Model and the Application of Conventional Learning Models International Journal of Contemporary Islamic Education, 1(1), 6785. constructive dialogue towards the advancement of modern technology where the principles of Islamic values provide a directional path for every Muslim to utilize and develop knowledge and technology as far as possible. It is no longer an Islamic value if its rules distort the creative space, initiative and personal sense of Muslims, thus leading to setbacks in all spheres of life.

In addition to instilling the values of Islam, Islamic Education also empowers the community to carry out these values dynamically and flexibly within the confines of the ideal configuration of God's revelation.

Worldly, for Islam contains ukhrawi values because with good deeds in the human world means we will be able to achieve happiness in the hereafter. Ukhrawi is the ultimate goal of Muslims' human life. It is this ultimate goal that drives his behavior in the world that is inseparable from the demands of his heavenly values.

Islamic education must be able to generate knowledgeable Muslims where faith and piety become controller in their application or practice in human society. If this is not the case, then the degree and dignity of his person as a servant of God will decline, and will even endanger other human beings. Therefore, the education system must emphasize the aspect of the faith in the idea of God, this is the value. While returning the origin of special events such as human creation as physical and spiritual beings is a belief.

\section{Methodology}


This study uses a qualitative approach with the object of research is high schools in the city of Palu. In this research, the writer took location in Bulagi district, Banggai regency.

The use of qualitative method in this study is based on several considerations. First, adjusting qualitative method is easier when dealing with multiple realities. ${ }^{12}$ Second, it can directly present the nature of the relationship between researchers and informants ${ }^{13}$. Third, this method is more sensitive and more adaptable to the many sharpening of the patterns of values encountered. ${ }^{14}$

The location used as a research site is in the district of Bulagi, Banggai Regency, Central Sulawesi Province, for various considerations, including: Bulagi is one of the Districts in the Banggai Kepulauan Regency which is the origin of the Banggai Kepulauan native community. Then there are a lot of Banggai Kepulauan native communities who live in Bulagi District, making it easier for writers to take the necessary data.

Data were collected using observation techniques, in-depth interviews and studies from shared

12 Nurdin, N. (2017b). To Research Online or Not to Research Online: Using Internet-Based Research in Islamic Studies Context. Indonesian Journal of Islam and Muslim Societies, 7(1), 31-54.

13 Nurdin, N. (2017a). Research in Online Space: The Use of Social Media for Research Setting Jurnal Sistem Informasi (Journal of Information System), 13(1), 67-77.

14Ibid., 5. written documents. ${ }^{15}$ While the data analysis is done using reduction and verification techniques with various data sources. The reduced data is then analyzed by claiming to the theoretical concepts used in this study.

\section{Result and Discussion}

4.1 The History of Bulagi Village

At the beginning, the name of the village was not Bulagi but the village of Bakiling which means dry, whose inhabitants came from Lipu Babasal. There are two brothers from there, one of whom lives in Bakiling while the other lives in Bunggukon (on the mountain). Gradually, many people settled, the tribe leaders was formed although the government was not formed as of now, and all problems were always handled by the tribe leaders ${ }^{16}$

It should be noted that the Bakiling village (dry) was originally Benseno or a small group with its leader referred as tonggol (village head). Gradually, because there were many tonggols appeared, Basalo was formed. Since Basalo was increased in numbers and met the requirement that was having at least 10 Basalos, a kingdom was formed. It was named the KINGDOM OF COMBOLONS. The existence of the Kombolon kingdom did

15 Nurdin, N. (2016). The Roles of Information Technology in Islamic Bank Knowledge Management: A study of Two Syariah Banks in Palu. Hunafa: Jurnal Studia Islamika, 13(2), 181-217. https://doi.org/https://doi.org/10.24239/jsi.v1 3i2.444.181-217

${ }^{16}$ Aman Suludani, Kepala Adat, Wawancara, Bulagi 20 Mei 2018.

e-ISSN: $2715-4572$

p-ISSN: 2716-1439 
not last long because the King was unable to carry out his duties, then the Kombolon kingdom was handed over to the Banggai Kingdom. Therefore, at that time all that was left was Basalo domiciled in Bakiling (Bulagi). ${ }^{17}$

The name Bulagi was first introduced by a King of Banggai named MANDAPAR (Mandafar). Once, King Mandapar paid a visit to Basolo Bakiling to collect tax or Lulu Talu. Upon arriving at Bakiling, the king felt thirsty. He sent a man named Laso (male) to climb a coconut tree and take a young coconut. When Laso was climbing the coconut tree, it turned out that there was a kind of ant in the palm tree called Som. He was bitten by the Som and shouted. The King asked him, 'Bula?' (means why) then he answered, 'Som'. Finally the King named the place Bulagi Sosom which came from the word Bula (why) Som (black ant). ${ }^{18}$

From then on Bakiling was renamed Bulagi Sosom and the person who climbed the coconut tree was appointed as Basalo with the title Basalo Bulagi Sosom ruling the area from Taepa Buang, Batu Adeno (Sumondung), to Leme-Leme Village Tataba District.

\subsection{The concept of Pasai in marriage}

Pasai tradition is one of the traditions in the marriage process that has developed since the days of the ancients used to inhabit the village area of Bulagi. Since they still embraced the religion of Animism and Dynamism and took Tumbu Bisa as their god, this

${ }^{17}$ Aman Suludani, 2018.

18Aman Suludani, 2018 tradition has been carried out by the local community even though the exact time of practicing this tradition is not known with certainty. ${ }^{19}$

After the proposal has been approved by both parties, a meeting is arranged to discuss and determine the amount of assets (Pasai) asked from the man. The form of the pasai consists of several types :

a. The main asset is a treasure for mother and father (Tina Tamano custom). In the ancient times, the things given to the parents were usually in the form of two baki (trays) equipped with plates and bowls and one sago groves, meaning that their household will increase in wealth and their offspring and children are as numerous as a sago tree with many shoots. In it's development, the Tina Tamano custom can now be replaced by two male and female goats. ${ }^{20}$

b. Sai Batango which is a treasure that is spent or used up for marriage expenses. Mr. Harman explained that Sai Batango deamo konda sinua (Sai Batango is a treasure spent). Because in the past, money had not been widely circulated, what was used for Sai Batango's payments was antiques made of copper and brass in various forms as proposals. Over time, the shape of the pasai has shifted. ${ }^{21}$

For the current provisions of the pasai, when the families of the two

\footnotetext{
${ }^{19}$ Aman Suludani, 2018.

${ }^{20}$ Aman Suludani, 2018.

${ }^{21}$ Harman, Anggota Adat, Wawancara, Bulagi 20 Mei 2018.
}

e-ISSN: $2715-4572$

p-ISSN: 2716-1439 
parties gather together in the stage of pobisala harta (discussing assets), the pasai requested by the woman family has been specified in the form of certain records. These details are then left to the men family. The pasai that must be fulfilled by the men are put together in the details and must be fulfilled by the men. These details are including the things shared for the Tina Tamano custom, and the cost of implementing the marriage. But there are also cashed in cash handed over to the woman family who then divide it based on marital needs. ${ }^{22}$

Furthermore, Halimah also clarify in the interview that the author conducted by explaining that:

The form of the pasai has undergone many changes over time, usually in the form of money, rice, goats, bedding equipments, and others. ${ }^{23}$

The nominal amount of pasai for each marriage is also different. The wedding party is determined based on the amount of the Sai Batango given. The Banggai village community considers 10 - 20 million rupiahs to be reasonable in the community. If she is a respected and educated woman it is possible to reach 30 even up to 50 million. However, a big amount of Pasai doesn't always makes a festive party. ${ }^{24}$

\subsection{Factors underlying Pasai Tradition}

Some factors that cause the pasai tradition must be carried out include:

22Halima, Toko Perempuan, Wawancara, Bulagi 20 Mei 2018.

23Halima, 2018.

24Halima, 2018. a. Pasai tradition is carried out as a form of parents' wishes that their children pay back services by getting more pasai than the men who propose to them. Usually parents always mumble "oila nanggu nilat, mau tongo soisik nda lame - lamekene " (what we get, even just a little, we will celebrate it). This sentence explains that parents, especially mothers, said that they marry off their children, they expect nothing in return of their services. Even only a small amount of pasai can be an outpouring of parents' happiness. However, in exchange of the services of parents a child give out the pasai.

b. This tradition can help the woman's parents to ease burden on the marriage expenses because the whole families and relatives must be invited when the marriage takes place.

c. Pasai has never been abandoned by the Banggai tribe in the village of Banggai because since ancient times carrying out customary provisions is a must.

d. A girl who is given more pasai will increase the degree of her parents in the eyes of society.

Parents have struggled hard to send their children to school. So, when a man comes to propose bringing only some amount of dowry, he must be underestimated. Even though it does not mean to discriminate people but this remains a consideration of parents. 
Therefore, men or applicants must also know themselves. ${ }^{25}$

The information above shows that parents have struggled to raise their children, send their children to school. if a man came only carrying dowry, he would be underestimated by the woman. Although it does not mean to distinguish between one person and another, those who propose should be aware of the position of the women.

With this pasai tradition, the sense of help, kinship and mutual assistance between local communities is more pronounced. This is proven by the holding of a joint venture among families who are present at the pobisala harta, helping to cover the shortage of pasai which cannot be fulfilled by the man. ${ }^{26}$

\subsection{Procedures for pasai handover}

Pasai tradition is a sequence of marriage tradition carried by the Banggai village community with the following stages:

\section{a. Mansadai Process}

Mansadai is a proposal made by a man or his family to a woman or her family. ${ }^{27}$ A man seeking his mate can directly contact the parents of the woman. However, mostly in reality, men lack the courage to do so. Instead, he asks their parents to propose by sending a community leader with a pasadai (gift) sign of the proposal.

25Halima, 2018.

${ }^{26}$ Aman Suludani, 2018.

27Aman Suludani, 2018.
Pasadai which is usually carried is in the form of 4 red-feathered roosters, Banggai yams, 2 bunches of dried fish, 12 aromatic areca nuts, 12 betels and lime as needed while the woman's family prepares a red feathered hen. Before the opening ceremony begins, the male's family representative puts a rooster closer to the hen. If both chicken crow and cackle, this indicates that the proposal is accepted, as well as other parcels, if eaten by the women then the proposal is accepted. ${ }^{28}$

The value of the red feathered cockerel symbolizes that a man must be brave in making a decision. Banggai yam indicates that men must be able to cultivate forests to be planted. Besides, the fish symbolize that they can also become fishermen. Areca nut is a symbol of humility, honor, honesty, and a desire to work hard with sincerity. Betel is a symbol of love and respect for each other and the lime signifies a symbol of a clean and sincere heart. ${ }^{29}$

Finally, a messenger is sent to the man's family to inform the acceptance of the proposal. If the proposal is not accepted, the pasadai is returned.

\section{b. Proses pobisala harta}

After the proposal is accepted, the pobisala harta is held. It is seeking agreement on the amount of pasai and the determination of time to deliver the pasai.

The process of determining the amount of pasai is carried out through discussion. It takes protracted time from

\footnotetext{
${ }^{28}$ Aman Suludani, 2018.

29Tongo, 2018.
}

e-ISSN: 2715-4572

p-ISSN: 2716-1439 
both sides. Words must be chosen carefully because offending either party will lead to a long debate or worse, the matchmaking of their children will be canceled.

After the agreement are made, the relationship between the man and woman has been formalized. In the span of time between the pobisala harta until the man delivers the agreed pasai, the couple has officially engaged.

\section{c. The process of Baantar harta}

The next stage is baantar harta or the process of handing over the pasai to the woman. The procedure is attended by the two families, village and hamlets officials, and witnessed by the village priest while giving a congratulatory prayer for being able to fulfill the woman's request. ${ }^{30}$

Determination of wedding reception must be based on the circulation of stars and the count of the elders. Usually the village elders say ndondok ko tumbeno, ndondok ko luano, ndondok ko toluno, which means that the marriage is good to be held on a particular day because at the beginning (tumbeno) of marriage, the whole process of living the household life (koluano) until the end of the life (kotoluno), it will be endowed with good things. When the marriage time arrives, the man will be escorted to the woman's home to hold the wedding ceremony in traditional clothing and accompanied by traditional musical instruments and taran. However, as time progressed, the marriage ceremony began to be

30Aman Suludani, 2018. abandoned. Marriage can be implemented without the customary processes. ${ }^{31}$

\subsection{The effect of pasai tradition}

Pasai traditions affected the proposals and marriages to be held later. If the man cannot fulfill the request from the woman to provide the pasai upon agreement at the pobisala harta, then the marriage cannot take place even though the proposal has been accepted at the mansadai stage and the terms and conditions of marriage have been fulfilled. ${ }^{32}$

In the community, if the Pasai cannot be fulfilled based on the agreement, the marriage can still take place, but it is hindered. However, there is also a man who until the time agreed can not fulfill the pasai resigns from the marriage. 33

Fulfilling the request for pasai from the woman is mandatory because it is customary. As for people who do not use pasai, they can get married directly to KUA, but usually there are other causes in it (pregnancy outside marriage).

Pasai is considered necessary in a marriage. Indeed the Islamic religion requires dowry. However, in the village of Banggai itself in addition to the dowry, the pasai must also be fulfilled. Because speaking in the context of humanity, not everyone has good intentions. If the parents of the woman do not agree with the man, the pasai is usually requested as expensive as

\footnotetext{
31Aman Suludani, 2018.

32Aman Suludani, 2018.

${ }^{33}$ Aman Suludani, 2018.
}

e-ISSN: 2715-4572

p-ISSN: 2716-1439 
possible. They do it to hinder marriage or refuse so that the man can not meet the very high demand of woman's family. 34

Although the purpose is different from each party who carry it out, this tradition needs to be done even though the provisions do not exist in the marriage law, because this has been hereditary from the ancestors.

It has never been found in the village of Bulagi that marriages have failed after the agreement on the number of pasai is determined at the pobisala harta stage. Usually the marriage is only postponed or the man asks for more time. What often happens is the cancellation of the proposal because there is no agreement on the amount of pasai. ${ }^{35}$

Sometimes, there are in debt pasai. It happened in connection with the determination of the good day of the marriage set by the village elders. Usually the marriage takes place immediately even though the pasai has not been fulfilled. ${ }^{36}$

A very expensive pasai given by the man to the woman actually has an adverse effect. Finally, numbers of married couples who married at KUA are increased because they were pregnant out of wedlock.

\subsection{The wedding Process}

The process of holding a pasai in a traditional wedding ceremony is

\footnotetext{
34Wardin T, Kepala KUA, Wawancara, Bulagi 22 Mei 2018.

35Wardin T, 2018.

36Aman Suludani, 2018.
}

carried out in the afternoon after the Asr prayer or in the evening after the Isha prayer, by bringing the yield of the garden, which is three sugarcane trees uprooted from the roots to the leaves, five coconuts, three young coconuts and two ripe coconuts, one bunch firewood, one puff of water, ripe bananas, and other sweet fruits.

The values contained in some food items brought by the man's family can be explained as follows:

Three sugarcane trees, from the root to the leaves, are bound into one bunch. The meaning of the three trees is that the family consists of three levels of social strata, they are those who are wealthy or have certain positions, the middle class, and those who are lowincome or poor. The man must embrace all of them, without having to discriminate between one another, both in terms of relationships, and in terms of giving out something. ${ }^{37}$

The cane tree trunk consists of several segments. Every segment is sweet and some segments are less sweet, and some even tasteless. The point is, if the woman has a sister (sister-in-law), then when buying clothes for his wife, he should also buy for his wife's sister.

Another meaning in the segment of the sugarcane trunk is, that in facing and passing through married life is not always sweet and beautiful as some people imagine. A few obstacles must be faced. Some couples take shortcuts, divorced. Some find another young bride for unreasonable reasons such as

\footnotetext{
37Erwin Y, Tokoh Agama, Wawancara, Bulagi 23 Mei 2018.
}

e-ISSN: 2715-4572

p-ISSN: 2716-1439 
the wife is being old, unable to provide good serve, and so forth. ${ }^{38}$

The meaning of two young coconuts, is as a motivation for the two newlyweds, who are still young, not to waste the beautiful and sweetness of the newlywed bride in order to soon have a child.

\subsection{The values of Islamic Education in Banggai customary marriage}

Customs that are at the level of cultural values are very abstract, they are ideas that conceptualize the most valuable things in life. For example the value of Islamic education in Banggai customary marriages.

According to the the customary head, custom at the level of norms is cultural values that have been linked to certain roles. Role as a leader, and as a teacher for example brings a number of norms that become guidelines for his behavior in terms of playing his role in these various positions. ${ }^{39}$

Furthermore custom at the legal level consists of customary law and written law. Whereas customary special rules are the rules governing specific activities that are clear and limited in scope, for example manners as an inseparable part of the values of Islamic education. ${ }^{40}$

The diversity of custom in Indonesia, which is rich in culture and tradition, is considered to have potential value as an element of state empowerment. Therefore, various

38Erwin Y, 2018.

${ }^{39}$ Aman Suludani, 2018.

40Aman Suludani, 2018. elements that weakening them are expected to be reduced, and the reinforcing the love to the custom must always be improved. Unfortunately, the values that exist in the custom are harassed and no longer have values in the general public at this time. This condition can be considered very worrying.

The decline in the value of custom is reflected in several occurring cases, such as the compulsion to choose one of several approved religions determined by the government. For generations, it is not certain that the customary community accepts one of the five religions as an option. The condition is then considered as one of the elements that must be reduced. However, for the Banggai tribe who are entirely Muslim, the developing customs must be in accordance with the values of Islamic education.

The most worrying problem is especially the negative stigma that is often affixed to custom. It is on the view of retardation, primitive, and diversity of thought. As in the case of primitivethemed television shows broadcasted in television media, it is considered by some customary communities to be very painful and frightening. Because of that incident, the media is now also considered as one of the causes of the negative stigma. Another worrying stigma is the way of naming and symbols which often associated with customary communities. ${ }^{41}$

The naming of underdeveloped

${ }^{41}$ An Dj Masso, Kepala Desa, Wawancara, Bulagi 25 Mei 2018.

e-ISSN: 2715-4572

p-ISSN: 2716-1439 
and primitive regions clearly disrupts customs psychologically, because it is considered as an obstacle to Indonesia's progress. Yet personally, the customary community are those who continue to move and change, and adjust the times without forgetting the values of ancestors. Even the diversity of customary ways of thinking is then regarded as the cause of division. Such things should be an invaluable source of state wealth.

Marriage is not just an identity, because God encourages humans to undergo a marriage with a noble purpose, to raise self-esteem between man and woman, which can help controlling the emotions and desires, and provide a path and motivation to improve the welfare of humanity itself because in religious marriages there is a form of love touching and affection deeply and promises in the name of God.

When a pair of man and woman have been bound in an official marriage in religion or belief, then they should realize that they have decided and committed to unite before God, each other is a part that must build up and complement each other. The problem of wrong or right, like or dislike, is the shared responsibility and self-esteem. If you cannot have an awareness of it all, it means that the couple has made the wrong decision to marry at first. ${ }^{42}$

Nowadays, people easily say and decide to divorce, with the reason "no more harmony". An excuse to run away from promises and commitments that

42Wardin T, 2018. were made in the beginning. They think such reason make themselves as rationalists or thinking right. In fact, that brings down their self-esteem and their family. Every couple should try to replace the "no more harmony" with "how to keep being harmonous", as a form of commitment in making a marriage decision.

This is what the author meant that the true marriage is marrying as the religion guidance, which will give more motivation to build the relation. Or choose the worse case, forget about marital status and then take the free sex option. Perhaps it is more honorable than to underestimate an oath and commitment to marriage, which is clearly a form of self-betrayal before God the Most Gracious, the Most Merciful. Therefore, humans are taught education in order to understand the values contained in a marriage so that marriage is not just simply venting lust.

Fundamental Islamic values that contain absolutes for human life as individuals and as members of society do not tend to change to follow the human passions or wants that change according to the demands of social change. The absolute Islamic values of God will function as controllers or directors of the demands of social change and individual demands.

The hope of every person to become a man of faith and piety to God always exists, However, the reality proves that life is not just theorizing but is to be carried out as theories say, as long as it does not violate the customary law, state law, and especially the law of 
God. ${ }^{43}$

Theologically and sociologically, religion can be seen as an instrument for understanding the world. In that context, there is almost no difficulty for any religion to accept the premise. Theologically, especially Islam, it is due to the omnipresent nature of religion. It is, religion, both through the symbols or the values they contain are present everywhere, influencing and even shaping social, cultural, economic and political structures and public policies. With these characteristics, it is understood that wherever a religion is, it is expected to contribute value to all discourses of human activity including the contribution of Islamic educational values to Banggai customary marriages. Religion loaded with noble values is not necessarily in practice producing humans who uphold these values.

The noble purpose of marriage according to the Banggai customary custom is for husband and wife to implement Islamic shariah in their households. As follows:

\section{Kafa'ah in Islamic Perspective}

The influence of materialism has affected many parents. Nowadays, many parents have the idea that in choosing a mate for their children, considering the position, social status and descent is important. The degree of approppriateness is only measured through those matters. While religious considerations received less attention.

According to Islam, equality in marriage, is considered very important

43Sarpin D, 2018. because the similarity between both husband and wife that helps to establish and foster an Islamic household will be realized. According to Islam kafa'ah is only measured by the quality of one's faith, piety and morality, social status, heredity and others.

Then they remain equal and there is no obstacle for them to marry each other. It is obligatory for parents of young men and women who still have materialistic viewpoint to leave it and return to the Qur'an and Sunnah of the Prophet. ${ }^{44}$

\section{Choose the pious / pious}

The second contribution of Islamic values in marriage according to the Banggai tribe is that those who want to marry must choose a pious woman and women must choose pious men. It is through the path of poiyas (mutual love). These stages have the value of faith, shari'ah and morality. Thus, marriage according to custom has made a positive contribution to the values of Islamic education. ${ }^{45}$

Human marriage is a long journey full of twists and turns, sweet and bitter, joys and sorrows come to make the life of the household more colourful. Therefore, before the wedding, the prospective bridegroom must give out some form of requirements from his livelihood outcomes.

Finally the community will be fully aware that there was no difference between the lineage of the aristocracy

44Sarpin D, 2018.
45Sarpin D, 2018.

e-ISSN: 2715-4572

p-ISSN: 2716-1439 
with ordinary people, especially in the implementation of marriages according to the customs of the Banggai tribe. This is one of the contributions of Islamic education values according to the custom of the Banggai tribe which is marked by the amount of the dowry, or in Banggai known as the pasai.

Strictly speaking, what the author means by equal rights in marriage according to the Banggai customary belief is a balance between the levels of knowledge that bring forth a common understanding in addressing a problem being faced.

It was also stated by community leaders that the noble value of a person in marriage according to the customs of the Banggai tribe is the existence of understanding and at the same time the implementation of marriage based on Islamic teachings. ${ }^{46}$

\section{Kesimpulan}

After researching and observing the Pasai adat system carried out by the Bulagi village community, the writer can conclude that the islands of Banggai people living in Bulagi village of the Bulagi sub-district of Banggai Kepulauan Regency have practiced the pasai tradition for generations. Pasai tradition is carried out in sequences of mansadai (proposal), pobisala harta (determining the amount of pasai), bandoloi (engagement process or waiting period for a woman before the man does Baantar harta), Baantar harta (handing over the pasai) then determining

\footnotetext{
${ }^{46}$ Amundung, Tokoh Masyarakat, Wawancara, Bulagi 2 Juni 2018
}

marriage date. Pasai tradition is carried out with the intention of fulfilling the prevailing customary provisions and helping to meet the costs of holding a wedding on the side of woman's family.

The marriage according to the Banggai tribal custom consists of poiyas. In its implementation, there are symbols - which contain the values of Islamic education by going through several stages.

The contribution of Islamic education values to Banggai customary marriages in Kec. Bulagi are: A marriage according to the Banggai customs, carried out in accordance with customary paths and stages, is more steady in understanding the values of Islamic education. ${ }^{47}$ With the similarity, equality, and equivalence (kafa'ah in the Islamic concept) between husband and wife couples, the efforts to establish and foster Islamic households will be realized.

a. There is no obstacle for the people of Bulagi to marry one another if they have the quality of faith and piety and morality, social status, ancestry and others.

b. When Islamic civilization confronts foreign civilization, three attitudes emerge; first, the civilization will absorb the foreign civilization as long as it does not conflict with Islamic creed or teachings. Second, civilization will modify it if it has relevance.

${ }^{47}$ Rusli, R. (2009). Gagasan Khaled Abu Fadl tentang "Islam Moderat" versus "Islam Puritan" (Perspektif Sosiologi Pengetahuan). Jurnal Ilmiah Ilmu Ushuluddin, 8(1), 99-123.

e-ISSN: 2715-4572

p-ISSN: 2716-1439 
Third, civilization will be rejected if it is contrary to Islamic creed.

\section{REFERENCES}

Abubakar, H. Zainal Abidin, Kumpulan Peraturan Perundang-Undangan Peradilan Agama. Jakarta: Yayasan Al-Hikmah, 1993

Achamadi, Ilmu Pendidikan Islam. Salatiga: Fakultas Tarbiyah IAIN Walisongo, 1987

Adi, Rianto, Metodologi Penelitian Sosial dan Hukum. Jakarta: Granit, 2004

Afandi, Ali, Hukum Waris, Hukum Keluarga, Hukum Pembuktian. Jakarta: Rineka Cipta, 1997

Arikunto, Suharsimi, Manajemen Penelitian. Jakarta: Rineka Cipta, 2005

Suatu Pendekatan Praktek. Jakarta:

PT Renika Cipta, 2002

Prosedur Penelitian

Suatu Pendekatan Praktek. Jakarta:

PT. Rineka Cipta, 1996

Al-Thabathaba'I, al-Mizan Tafsir AlQur'an. Jakarta: Raja Grafindo Persada, 1991

Amir Suma, Muhammad, Hukum Keluarga Islam di Dunia Islam. Jakarta: Raja Grafindo Persada, 2004

Anshary MK, Hukum Perkawinan di Indonesia Masalah-masalah

Kursial. Yokyakarta: Pustaka Pelajar, 2010
Azhar Basyir, Ahmad, Hukum Perkawinan Islam. Yogyakarta: UII Press, 2000

Azra, Azumardi, Pergolakan Politik Islam. Jakarta: Paramadina, 1996

-------------, Perspektif Islam di Asia Tenggara. Jakarta: Yayasan Obor Indonesia, 1989

------------, Filsafat Pendidikan Islam. Jakarta: Bumi Aksara, 1994

$\begin{array}{ccc}\text { Pendidikan. Jakarta: } & \text { Religi- } \\ \text { PTPPLPTK, } 1988 & \text { Dirjen }\end{array}$

Arifin, HM, Ilmu Pendidikan Islam Suatu Tinjauan Teoritis dan Praktis Berdasarkan Pendekatan Interdisipliner. Jakarta: Bumi aksara, 1991

B. Taneka, Sulaiman, Hukum Adat Suatu Pengantar Awal dan Prediksi Masa Depan. Bandung: E.esco, 1987

Burhan, Bungin, Metode Penelitian Kualitatif. Jakarta: PT. Raja Grafindo Persada, 2003

Casser Ernits, Manusia dan Kebudayaa. Jakarta: PT Gramedia, 1987

D. Marimba, Ahmad, Filsafat Pendidikan Islam. Bandung: Al-Maarif, 1989

Departemen Agama RI, Al-Qur'an dan Terjemahnya. Semarang: CV. Toha Putra, 1996

Evita, E., Syahid, A., \& Nurdin, N. (2019). Understanding Students' Learning Outcomes Differences Through the Application of the Market Place Activity Type of Cooperative Learning Model and the Application of Conventional Learning Models International Journal of

e-ISSN: 2715-4572

p-ISSN: 2716-1439 
Contemporary Islamic Education, 1(1), 67-85.

Hadi, Sutrisno, Metodologi Penelitian. Yogyakarta: Andi Ooffset, 1989

Hadikusuma, Hilman, Hukum Perkawinan Adat. Bandung: Alumi, 1983

Hartoko, Dick, Strategi Kebudayaan. Yogyakarta: Kanisius, 1988

Hasan Sulaiman, Fathiyah, Sistem Pendidikan Versi al-Ghazali. Bandung: Al-Maarif, 1986

Hazairin, Tinjauan mengenai UU Perkawinan Nomor: 1 - 1974. Jakarta: Tintamas, 1986

Huky, Wila, Pengantar Sosiologi. Surabaya: Usaha Nsional, 1982

Katu, Samiang, Pasang Ri Kajang: Kajian tentang Akomodasi Islam dengan Budaya Lokal di Sulawesi Selatan. Makassar: PPIM; 2000

Kountur, Ronny, Metode Penelitian Untuk Penulisan Skripsi dan Tesis. Jakarta: PPM, 2007

Madjid, Nurcholish, Islam Doktrin dan Peradaban. Jakarta: Paramadina, 1992

Magnis Suseno, Franz, Berfilsafat dari konteks. Jakarta: Gramedia, 1991

Manan, Abdul Reformasi Hukum Islam di Indonesia. Jakarta: PT Raja Grafindo Persada, 2006

Moleong, Lexy J, Metodologi Penelitian Kualitatif. Bandung: PT. Remaja Rosdakarya, 2001

Kualitatif. Bandung: Remaja
Rosdakarya, 1997 Perubahan Sosial Suatu Teori Pendidikan. Yogyakarta: Rake Sarasi, IV 1987
Muhaimin, Paradigma Pendidikan Islam, Upaya Mengefektifkan Pendidikan Agama Islam di Sekolah. Bandung: PT Remaja Rosdakarya Offset, 2001

Muhaimin. Pemikiran Pendidikan Islam. Bandung: Trigrnda Karya. 1996

Muhammad Noor Syam, Filsafat Pendidikan dan Dasar Filsafat Pendidikan Pancasila. Surabaya: Usaha Nasional, 1986

M. Qurais Shihab, Tafsir Al-Misbah. Bandung: PT Remaja Rosdakarya, 2009

--_----, Wawasan Al-Qur'an Tafsir Maudhu'I atas Berbagai Persoalan Umat, Selanjutnya disebut Wawasan). Jakarta: Mizan, 1990

Notowigdagno, Rohiman, Ilmu Budaya Dasar Berdasarkan Al-Qur'an dan Hadits. Jakarta: Taragrafindo Persada, 2000

Nurdin, N. (2016). The Roles of Information Technology in Islamic Bank Knowledge Management: A study of Two Syariah Banks in Palu. Hunafa: Jurnal Studia Islamika, 13(2), 181217.

https:/ /doi.org/https:/ / doi.org/ 10.24239/jsi.v13i2.444.181-217

Nurdin, N. (2017a). Research in Online Space: The Use of Social Media for Research Setting Jurnal Sistem Informasi (Journal of Information System), 13(1), 67-77.

Nurdin, N. (2017b). To Research Online or Not to Research Online: Using Internet-Based Research in Islamic Studies Context. Indonesian Journal of Islam and Muslim Societies, 7(1), 31-54.

e-ISSN: $2715-4572$

p-ISSN: 2716-1439 
Raga Maran, Rafael, Manusia Dan Kebudayaan dalam Perspektif Ilmu Budaya Dasar. Jakarta : Rineka Cipta, 2007

Rahman, Jalaluddin, Islam dan Perspektif Pemikiran Kontemporer . PT. Umitoha, 1997

Rasyid Ridha, Muhammad, Tafsir alQur'an al-Hakim. Semarang: CV. Toha Putra, 1996

Ricklefs, M. C, Sejarah Indonesia Modern. Yogyakarta: Gajah Mada University Press, 1991

Ridwan, Skala Pengukuran Variabelvariabel Penelitian. Bandung: Alfabeta, 2011

Rohimin, Harmonisasi Agama dan Budaya di Indonesia. Jakarta: PT. Nusantara lestari Ceriapratama, 2009

Rusli, R. (2013). The Role of Musalahah in Conflict Resolution: A Historical Perspective. Hunafa: Jurnal Studia Islamika, 10(2), 203220.

Rusli, R. (2009). Gagasan Khaled Abu Fadl tentang "Islam Moderat" versus "Islam Puritan" (Perspektif Sosiologi Pengetahuan). Jurnal Ilmiah Ilmu Ushuluddin, 8(1), 99123.

S. Margono, Metodologi Penelitian Pendidikan. Jakarta: Renika Cipta, 1999

Saefuddin Anshari, Endang, Ilmu, Filsafat, dan Agama. Surabaya: Bina Ilmu, 1987

Saleh, K. Wantjik, Hukum Perkawinan Indonesia. Jakarta : Ghalia Indonesia, 1976
Saryono, Metodologi Penelitian Kualitatif dalam Bidang Kesehatan.Yogyakarta: Nuha Medika 2010

Situmorang, Victor, Kedudukan Wanita di Mata Hukum. Jakarta : Bina Aksara, 1998

Subekti, Pokok-pokok Hukum Perdata. Jakarta: CV Bimbingan, 1962

Sudarsono, Hukum Perkawinan Nasional. Jakarta: PT.Rineka Cipta, 1991

Sudiyat, Iman, Asas-Asas Hukum Adat Bekal Pengantar. Yogyakarta : Liberty, 1978

Sugiyono, Metodologi Penelitian Kombinasi (Mixed Methods). Bandung: Alfabeta, 2012

-----------, Metode Penelitian Pendidikan Pendekatan Kuantitatiff, Kualitatif, dan RED. Bandung: Alfabeta, 2010

Sukandarrumidi, Metodologi Penelitian. Yogyakarta: Gajah Mada University Press, 2004

Syaltout, Mahmud, al Islam 'Aqidah wa Syari'ah. Jakarta: Putaka Amani, 1986

Syarifuddin, Amir, Hukum Perkawinan Islam di Indonesia Antara Figh Munakahat dan Undang-Undang Perkawinan. Jakarta: Kencana, 2011

Tafsir, Ahmat, Ilmu Pendidikan dalam Pespektif Islam. Bandung: Remaja Rosdakarya, 2001

Thoha, Ghabib, Kapita selekta Pendidikan Islam. Yogyakarta: Pustaka Pelajar, 1996

Tim Depdikbud RI, Kamus Besar Bahasa Indonesia. Jakarta: Balai Pustaka, e-ISSN: 2715-4572 p-ISSN: 2716-1439 
International Journal of Contemporary Islamic Education

Vol. 2 No. 1 Tahun 2020

1989

Tim Penyusun SKI UIN Sunan Kalijaga

Yogyakarta, Sejarah Peradaban Islam

di Indonesia. Yogyakarta: Pustaka, 2006

Trianto, Perkawinan Adat. Jakarta:

Prestasi Pustaka Publisher, 2007

Wahab Khallaf, Abdul, Ilmu Ushul Fighi. Indonesia: al-Haramain, 2004

Wingjodipoero, Soerojo, Pengantar dan Azas-Azas Hukum Adat. Jakarta: Gunung Agung, 1997

Wirjono Prodjodikoro, Hukum

Perkawinan Indonesia. Bandung : Sumur, 1974

Yahya, Mukhtar, Dasar-Dasar Pembinaan Hukum Islam. Bandung: PT. AlMa'arif, 1997

Zakiah Drajat, Ilmu Pendidikan Islam. Jakarta: PT. Bumi Aksara, 2000 